\author{
FANPAGE JAKO AMATORSKI SŁOWNIK GWAROWY \\ Btażej Osowski, \\ dr hab., Wydzial Filologii Polskiej i Klasycznej \\ Uniwersytet im. Adama Mickiewicza w Poznaniu \\ (Poznań, Polska) \\ e-mail: blazej.osowski@amu.edu.pl \\ ORCID: 0000-0002-4226-1378
}

Artykut opisuje, jak w nowych mediach (Internecie) adaptowane sq tradycyjne formy opracowania słownictwa gwarowego. Na Facebooku odnaleźć można liczne fanpage'e poświęcone tematyce gwarowej. Należy do nich Dawniej tutej - gwara wielkopolska, z którego pochodzi analizowany materiat. Adaptując terminologię tradycyjnej leksykografii, $w$ artykule analizie poddano układ haset oraz budowe artykut hasłowego. W porównaniu ze słownikami papierowymi zwraca uwagę udział elementów graficznych oraz uwzględnienie potrzeb oraz możliwości percepcji odbiorcy.

Stowa kluczowe: dialektologia, Internet, fanpage, post, stownik gwarowy, leksykografia, uktad stownika, artykut hastowy.

Postawienie problemu. Fanpage to utworzona na portalu społecznościowym Facebook strona dla fanów znanej osoby, zespołu muzycznego, drużyny sportowej, zjawiska społecznego itd. W tej różnorodnej, wirtualnej przestrzeni znalazło się także miejsce dla fanów (czy może raczej: sympatyków) gwary. Jest to dla dialektologa zjawisko niezmiernie interesujące choćby ze względu na pojawienie się elementów gwarowych w kodzie pisanym, podczas gdy pierwotną domeną używania gwary jest odmiana mówiona języka.

Spośród licznych fanpage'y poświęconych tematyce gwarowej wybrałem Dawniej tutej gwara wielkopolska, ponieważ jest to jedna ze starszych tego typu stron. Istnieje od 2013 roku$^{1} \mathrm{i}$ skupia ponad 42000 użytkowników. Fanpage został założony, by umożliwić poznanie «gwary poznańskiej w jej kościańskim odcieniu». Powiązany jest $\mathrm{z}$ dźwiękowym serwisem gwarowym założonym $z$ inicjatywy samorządu Kościana (dawniejtutej.pl). Osoby prowadzące fanpage nie zajmują się zawodowo językoznawstwem ${ }^{2}$, zaś przy publikowaniu postów korzystają ze zbiorów własnych oraz słowników - Słownika gwary miejskiej Poznania pod red. M. Gruchmanowej i B. Walczaka oraz Stownika gwary poznańskiej W. Wierzby.

Udostępniane przez Dawniej tutej... treści mają różnorodny charakter, jednak zasadniczo widać w nich hybrydowe formy prezentacji treści - połączenie tekstu i grafiki. Symbioza tych dwóch kodów ma wielowymiarowy charakter - tekst wprowadza grafikę i ponadto jest jej częścią: 1) grafikę stanowi tekst na kolorowym tle (bez innych elementów służących egzemplifikacji lub dekoracji), 2) tekst jest częścią grafiki, na którą ponadto składają się elementy o charakterze egzemplifikacyjnym lub ozdobnym (por. przykłady 1 i 2). Możliwy jest też trzeci typ postów, w których pojawia się tylko kod tekstowy bez graficznego, który jednak w badanym materiale nie wystąpił. Wynika to $\mathrm{z}$ faktu, że obrazki na fanpage'ach stosuje się, by przyciągnać uwagę użytkowników; posty zawierające wyłącznie tekst «gorzej się klikają».

\footnotetext{
${ }^{1}$ Poniższe dane na podstawie sekcji Informacje analizowanego fanpage'a.

${ }^{2}$ Niniejsze opracowanie wpisuje się poniekąd w nurt prac poświęconych recepcji naukowego stanu wiedzy przez niespecjalistów - por. Walczak 2013.
} 


\section{nowe lotko}

Nowe lotko, maik, gaik to zwyczaj obchodzenia domów $z$ sosnową lub świerkową gałązką, która jest symbolem nadchodzącej wiosny. Chodzące z nowym lotkiem dzieci śpiewały:

Pani gospodyni, nowe lotko stoi w siyni. Jeśli chcecie łoglundować to musicie coś darować. Zielony gaj, koszyczek jaj..

W podziękowaniu za wizytę gospodyni obdarowywała dzieci jajkami, plackami lub drobnymi pieniędzmi.

Dawniej tutej ...wew Koscianie. Gwara wielkopolska

Przykład 1. $(21.03 .2020)^{3}$

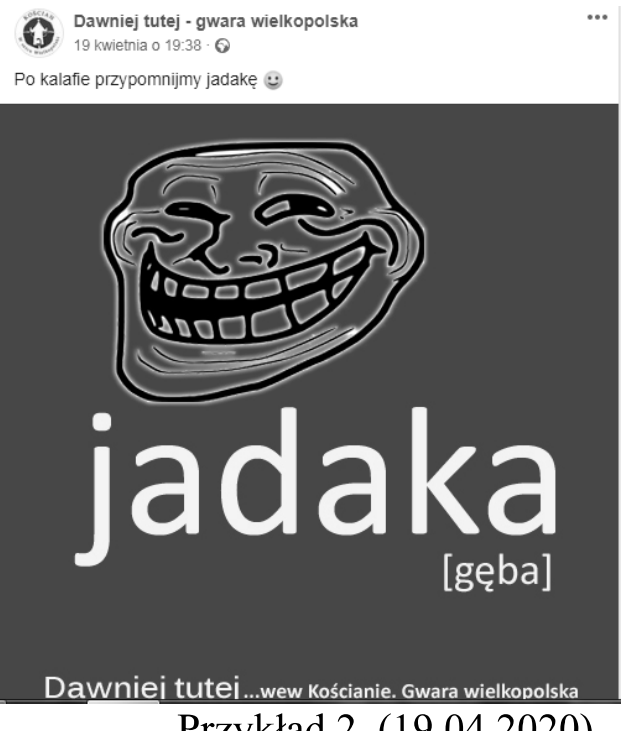

Używam określenia słownik, stosując pewne rozszerzenie semantyczne, ponieważ zgodnie z założeniem P. Żmigrodzkiego słownik elektroniczny jest zbiorem danych informatycznych, który można przeszukiwać $\mathrm{w}$ celu znalezienia informacji przez programy komputerowe $\mathrm{i}$ inne urządzenia związane z techniką komputerową [21, s. 100]. Tymczasem fanpage przeszukiwalny jest tylko częściowo - możliwe jest to w przypadku tekstu, ale nie dotyczy już grafiki. Niemniej również wspomniany badacz, opisując słowniki w witrynach prywatnych, stwierdza, że nie występują w nich narzędzia do przeszukiwania [20, s. 257]. Jest to zrozumiałe - aby wykorzystać tego typu narzędzia, trzeba mieć umiejętności programowania lub zasoby finansowe, by za nie zapłacić, czego leksykograf-amator zazwyczaj jest pozbawiony.

Analiza innych badań i publikacji. Internet przez niektórych badaczy postrzegany jest jako szansa dla języków mniejszościowych i zagrożonych [4, s. 3; 8, s. 25]. Podobnie jako szansę postrzegać go można wobec odmian terytorialnych języka, choć wątek ten w literaturze jest rzadko poruszany i wymagałby dokładnego opracowania. J. Grzenia, autor monografii Komunikacja językowa $w$ Internecie, stwierdza, że «globalny Internet może im [terytorialnym odmianom języka - B.O.] dać wiele dobrego, gdyż umożliwia upowszechnianie form regionalnych i gwarowych, a także ich utrwalanie [...], trzeba uznać, że nawet gwary, choć w niewielkim stopniu, korzystają z dobrodziejstw komunikacji internetowej» [10, s. 183-184].

Do tej pory dysponujemy badaniami szczegółowymi rozproszonymi w czasopismach lub opracowaniach zbiorowych. Uwagę poświęcono gwarom wielkopolskim [2, 3], śląskim [13], krakowskim [19] czy podlaskim [5]. Nieliczne są teksty o charakterze ogólniejszym, np. poświęcone frazeologizmom gwarowym w Internecie [12] czy gwarom słowiańskim na Facebooku [14].

Metoda pracy. Badacze Internetu wskazują, że analiza tego medium powinna uwzględniać związki między producentami i użytkownikami materiałów zamieszczonych w sieci $[15$, s. 28]. W niniejszej pracy analizie poddano tylko jedną stronę tej relacji, tj. grafiki publikowane przez twórcę fanpage'a. Ściślej rzecz ujmując, zajmuję się postami o charakterze słownikowym. Za takie uznaję najprostszą postać hasła występującego w słownikach amatorskich, tj. połączenie wyrazu gwarowego $\mathrm{z}$ jego definicją w odmianie ogólnopolskiej. Założyłem, że do połączenia tego dochodzi w obrębie grafiki ${ }^{4}$, ponieważ dla technologii cyfrowych typowe jest zjawisko konwergencji, tj. zacierania granic między tekstem, obrazem i

\footnotetext{
${ }^{3} \mathrm{~W}$ nawiasie podaję datę publikacji danej grafiki. Wszystkie przykłady pochodzą $\mathrm{z}$ analizowanego fanpage'a Dawniej tutej...

${ }^{4}$ Wiele $\mathrm{z}$ tych grafik określić by można mianem memu internetowego, tj. informacji, która dzięki swojej popularności jest przekazywana między internautami [17, s. 131].
} 
dźwiękiem [1, s. 316]. Jak stwierdza Jan van Dijk, «[w] trybie lingwistycznym rośnie znaczenie wariantu audiowizualnego (teksty, którym towarzyszą obrazy i dźwięki) kosztem wariantów oralnego i pisemnego. Wzrosła rola trybu ikonicznego, przybierającego postać filmów, zdjęć, rysunków, wykresów, okienek i innych form graficznych» [9, s. 296]. Pozagraficzna część tekstowa służy natomiast innym celom - przede wszystkim zagajeniu kontaktu, np. Dziś słowo niebezpieczne (28.04.2020), Uwaga! Trzeba ja teraz zasłaniać (15.04.2020), A może by tak... (30.03.2020).

Tym samym na analizowany materiał złożyło się 100 postów o charakterze słownikowym zamieszczonych w okresie 11.02.2019-30.04.2020. We wskazanym przedziale czasu opublikowano łącznie 131 postów, lecz 31 prezentowało typ inny niż słownikowy. Są to m.in. czasu opublikowano łącznie 131 postów, lecz 31 prezentowało typ inny niż słownikowy. Są to m.in. posty okolicznościowe, związane $\mathrm{z}$ rocznicami ważnych wydarzeń, przypadającymi świętami, obchodzonymi tradycjami, teksty w całości gwarowe - por. przykłady 3-5:

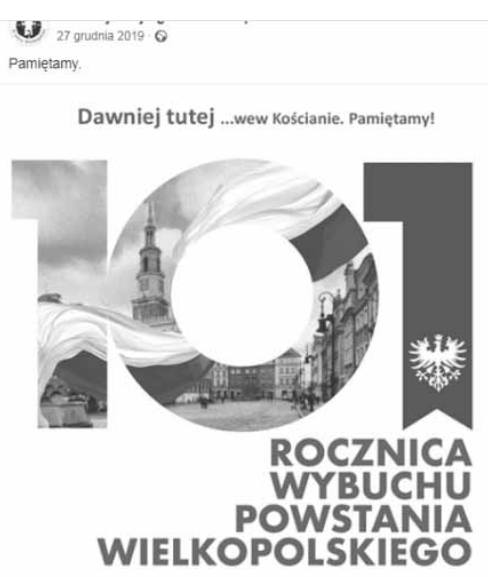

Przykład 3. (27.12.2019)

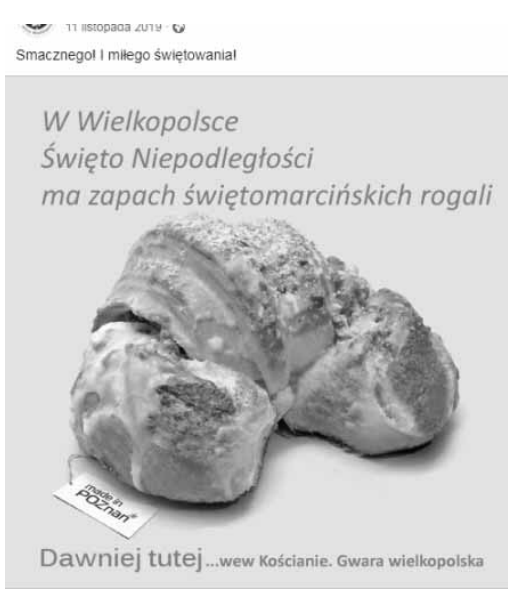

Przykład 4. (11.11.2019)

\section{Rosół zez kury}

Umytygo kuroka utunkać wew gorku zes

zimnum wodum, dziepko posolić i pocukrzyć.

Zaś potym zagotować i zebrać farfocle.

Do takiygo wywaru dodać obmytum

włoszczyzne i gotować na małym ogniu

mniy wiyncyj bez jednym godzine

oź kurok bydzie miynki.

Zaś potym wyjuć unygo zes rosołu, a rosót doprawic do smaki.

Podawać zez zieleninum i makarunym abo zez plutymi kluskami.

smacznego zyczy dawniejtutej.pl - gwara wielkopolske

Przykład 5. (7.12.2019)

Jak łatwo można zatem policzyć, posty słownikowe stanowią $76 \%$ wszystkich. Ze względu na ich liczebność warto im się przyjrzeć bliżej. Celem artykułu jest analiza układu haseł oraz budowy artykułu hasłowego ${ }^{5}$.

Analiza materiału. W pierwszej kolejności scharakteryzowany zostanie układ hasel. W przypadku Dawniej tutej... musimy pamiętać, że hasła słownikowe są tylko jednym z typów udostępnianych postów. Publikowane są w seriach przerywanych postami rocznicowymi, wiadomościami od czytelników itd. Wspomniana nieciągłość nie pozwala mówić o analizowanym fanpage'u jako o słowniku, tj. publikacji z wyodrębnioną częścią gromadzącą hasła ułożone wg zasady określonej przez autora. Mamy do czynienia ze zbiorem haseł słownikowych, które publikowane są wg zmiennych kryteriów. Wspomniany zbiór ma ponadto charakter otwarty (cały czas przybywają nowe posty), co również utrudnia autorowi przyjęcie jednej koncepcji porządkowania haseł.

Wobec powyższego nie dziwi, że w Dawniej tutej... nie wykorzystano systematycznie żadnego z układów haseł stosowanych w naukowych publikacjach słownikowych. H. Karaś stwierdza, że w polskich słownikach gwarowych najczęściej stosuje się układ alfabetyczny, następnie rzeczowy, zaś gniazdowy występuje niezwykle rzadko i niezbyt konsekwentnie jako uzupełnienie układu alfabetycznego [11, s. 132-135]. Słowniki naukowe, których celem jest dokumentowanie i eksplikacja słownictwa, muszą gwarantować szybkie dotarcie do poszukiwanego słowa, stąd stosowanie układu alfabetycznego. Układ ideograficzny zadomowił się natomiast w słownikach synonimów [20, s. 181], zaś tematyczne uporządkowanie leksyki

\footnotetext{
${ }^{5}$ Omawiając zebrany materiał, wykorzystuję terminologię tradycyjnej leksykografii, choć jest to tylko adaptacja pojęć i terminów, materiał internetowy jest bowiem odmienny od słowników naukowych.
} 
najczęściej wykorzystywane jest $\mathrm{w}$ dziełach dwujęzycznych o charakterze dydaktycznym [6, s. 40]. W Dawniej tutej... cele są inne. Chodzi o przypominanie słownictwa gwarowego,

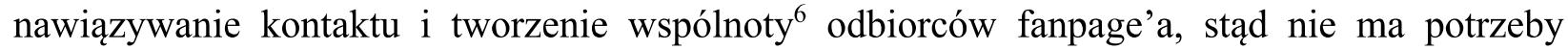
porządkowania leksyki. Do publikacji wybiera się hasła atrakcyjne, wywołujące zaciekawienie, które sprowokują czytelników do komentowania. Język jest nie tylko medium komunikacji, ale i jej przedmiotem, dlatego w Internecie język «przede wszystkim ma przyciągać uwagę odbiorców» [17, s. 120].

Jeśli pojawiają się serie powiązanych haseł, to nie mają one charakteru uporządkowanego; tworzą raczej kolekcje złożone $z$ luźno powiązanych elementów. Kolekcje mogą być wyodrębniane na zasadzie semantycznej lub formalnej. Do pierwszego typu należą przykładowo ZUPY lub OWOCE. W ramach kolekcji ZUPY opublikowano hasła ślepe ryby (26.02.2020), rumpuć/rampuć (2.03.2020), repeta (8.03.2020), w kolekcji OWOCE znajdziemy Drzuzgawka (21.06.2019), świyntojanki (23.06.2019), smrodyle smrodyny (26.06.2019), angryst (1.07.2019). Jak widać, wewnątrz kolekcji hasła nie są uporządkowane alfabetycznie. Ponadto nie ma konsekwentnie obowiązującej zasady rządzącej przejściami pomiędzy poszczególnymi kolekcjami czy hasłami wewnątrz kolekcji, np. przed serią ZUPY opublikowano hasło Co ja za to moge?? 'co ja na to poradzę' (23.02.2020), a po niej churchać churchlać 'kaszleć' (12.03.2020), serię OWOCE poprzedzało hasło bachać się 'kąpać się' (17.06.2019), a następowało po niej kulać 'toczyć' (4.07.2019). Trudno dostrzec tu powiązania semantyczne czy formalne.

Kolekcję mogą też tworzyć elementy podobne pod względem formalnym. Na takiej zasadzie połączono hasło Elegant z Mosiny (24.01.2020) z innym frazeologizmem Pierdoła $z$ Gądek (28.1.2020) a następnie to hasło z pierdolić (1.02.2020) czy teściu (10.08.2019) i wuja (12.08.2019), które zestawiono na zasadzie podobieństwa fleksyjnego (ich mianownik w gwarach wielkopolskich równy jest innym przypadkom w języku ogólnym). Nawigacja między elementami kolekcji odbywa się w części pozagraficznej postu i ma charakter addytywny (nowszy post odsyła do starszego), co wskazywałoby na brak planu publikacji kolejnych postów (co umożliwiałoby w postach wcześniejszych zapowiadanie postów późniejszych). Jednak analiza części pozagraficznej postów znajduje się poza obszarem interesującym mnie w tym artykule i wymagałaby dalszych badań.

W analizowanym materiale znajdujemy także ślady układu gniazdowego. W jednym poście-artykule hasłowym pojawiają się warianty morfologiczne wyrazu, np. sznajderka sznajdera 'proca' (25.03.2020), gis gisówa 'deszcz, ulewa' (9.09.2019), październik i paździerz 'mizerota, ktoś niewysoki, szczupły' (30.09.2019), także czasownik i jego formy prefigowane, np. lyra się i wylyrała się (5.11.2019), różne części mowy zawierające ten sam temat słowotwórczy, np. ligawa 'lodowisko' i ligać sie 'jeździć na łyżwach' (2.01.2020), futrować 'karmić zwierzęta' i futer 'pasza, pożywienie' (21.03.2019), migana 'zabawa taneczna' i migać 'tańczyć' (25.02.2019). W jednym poście łączy się również wyrazy o odmiennym pochodzeniu i znaczeniu, ale brzmiące podobnie, np. pora 'warzywo por' i pory 'spodnie' (11.09.2019).

Wymienione powyżej układy haseł znamy z tradycyjnych słowników naukowych, choć jak widać układy te ulegają znacznym przeobrażeniom ze względu na odmienne cele, które stawiają sobie autorzy opracowań nieprofesjonalnych. W Dawniej tutej... znaleźć można jeszcze jeden typ układu haseł, który pojawia się bodaj najczęściej. Jest to układ motywowany okolicznościami pozajęzykowymi, takimi jak aktualny stan pogody, zbliżające się lub obchodzone święta, tradycje regionalne, rocznice ważnych wydarzeń. Występowanie haseł ściśle związanych z kontekstem ma zwiększyć liczbę odbiorców, np. post z 31.07.2019 zaczyna się od słów Po upałach przyszedt (na szczęście) gis... i grafika poświęcona jest hasłom gis i

\footnotetext{
${ }^{6}$ Wspólnotowość zainteresowań jest podstawową potrzebą budującą więzi między członkami cyberspołeczności [16, s. 20]. O motywacjach do prowadzenia fanpage'y gwarowych, w tym o tworzeniu wspólnoty - por.: [14, s. 227-230].
} 
gisówa. Z kolei post z 18.04.2019 związany był ze zbliżającymi się świętami wielkanocnymi. Powtarzalność tych okoliczności sprawia, że niektóre hasła pojawiają się po kilka razy (co w słownikach tradycyjnych nie jest akceptowane), np. wspomniane hasło gis gisówa w analizowanym materiale wystąpiło 31.07.2019 i i 9.09.2019, zaś hasło o zajączku wielkanocnym 18.04.2019 i 9.04.2020. W takich sytuacjach niezmienionemu obrazkowi towarzyszy najczęściej inna forma części pozagraficznej, np. post o zajączku z 2019 r. zaczyna się od słów: U nas zawsze w Wielki Czwartek. W tym roku też przyszedt :), natomiast w 2020 r. od słów: U nas już byt. A do Was kiedy przychodzi?

Jeśli chodzi o budowę artykułu hasłowego, to jak pokazuje Wykres 1. warunkiem niemal koniecznym zaistnienia artykułu hasłowego jest wystąpienie wyrazu hasłowego. Co prawda w Dawniej tutej... pojawiają się posty z ukrytym wyrazem hasłowym (por. przykład 6) ${ }^{7}$. Jednak są to przypadki marginalne i w $99 \%$ badanych postów lemma występuje jako wyodrębniona część artykułu.

Niemal równie często pojawia się definicja - 91\%. Do częstszych składników artykułu hasłowego na analizowanym fanpage'u należy jeszcze ilustracja graficzna $-72 \%$. Jej duża frekwencja wynika z wcześniej opisywanej atrakcyjności kodu wizualnego. Można przyjąć, że te trzy składniki konstytuują hasło słownikowe na fanpage'u. Pozostałe elementy występują o wiele rzadziej. Cytaty pokazujące przykład użycia hasła wystąpiły tylko w $28 \%$ artykułów, warianty morfologiczne, fonetyczne i leksykalne - 16\%, hasło towarzyszące - $8 \%$, kwalifikatory i stałe połączenia wyrazowe - po $4 \%$, etymologia - $2 \%$.

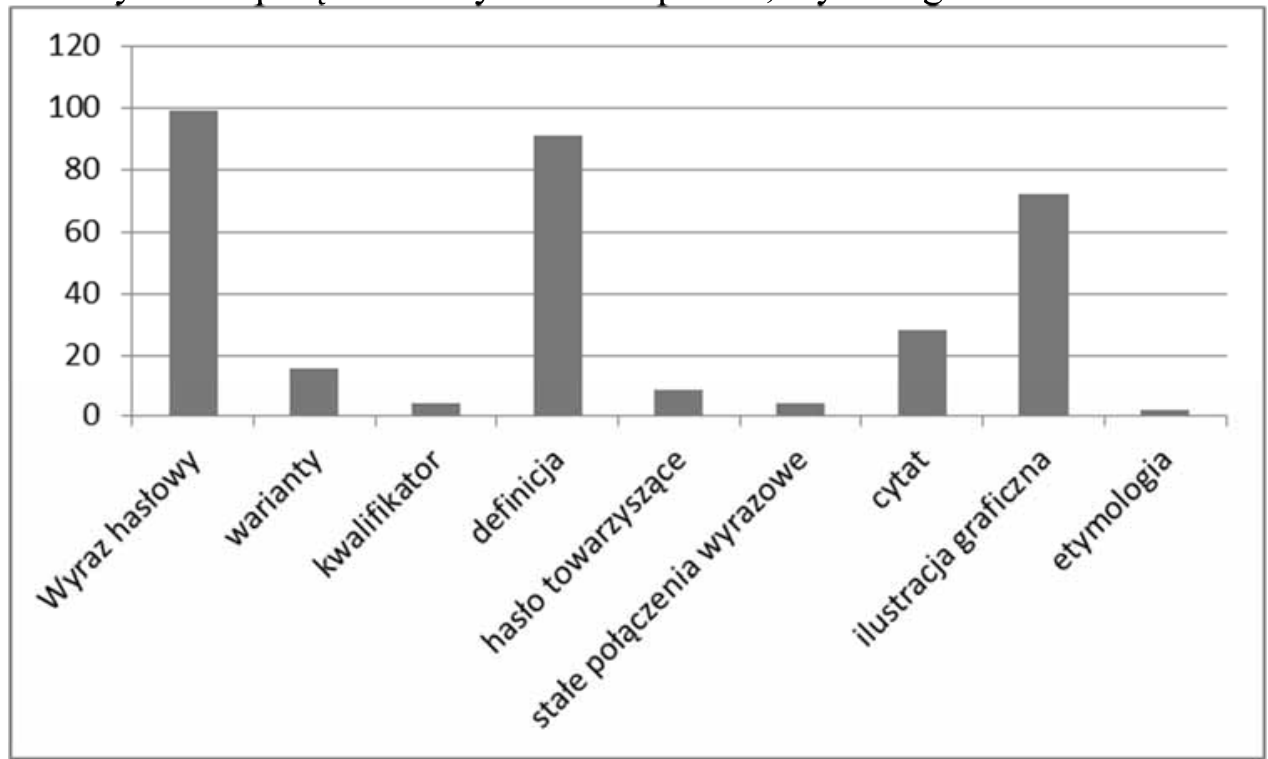

Wykres 1. Występowanie składowych hasła słownikowego

Budowa artykułu hasłowego jest zmienna - zarówno jeśli chodzi o występowanie poszczególnych elementów, jak i ich kolejność. Nie ma też stałych środków oznaczania poszczególnych składników hasła, raz więc hasło zapisane jest czcionką większą, raz pogrubioną, raz zaczyna się wielką literą, a raz małą, definicja raz zapisywana jest w nawiasie kwadratowym, raz bez niego, raz ma postać równoważnika zdania, a innym razem zdania itd. Zmienny skład artykułu hasłowego może być wynikiem braków w technice opracowywania haseł, jak również może być powodowany chęcią uniknięcia monotonii, która dla internauty nie jest atrakcyjna.

Grafikę z badanych postów słownikowych cechuje nie tylko płynność struktury, ale w wielu przypadkach także narracyjność, np. kwirlejka 'Zapytaliśmy gości Dawniej tutej o to, jak

\footnotetext{
${ }^{7}$ W tym przypadku za uznaniem frazy Nabolałe jabza za wyraz hasłowy przemawia wyodrębnienie jej w osobnym wersie oraz inicjalna pozycja wśród elementów grafiki.
} 
w ich domach mówią na «mątewkę». Dla większości jest to kwirlejka, ale są i takie nazwy: firlajka, firlołka, firlejek, kwyrlejka, kwirlołek, koziołek, firlok, firloczek, firlejka, firlok (!), kwyrla, kołtuszka, turlejka, kwirla, rogólka, firlitko, kołotuszka, fyrlaczka, kurlejka...' (24.08.2019) czy 25 grudnia obchodzimy pierwsze święto 26 grudnia celebrujemy drugie święto $i$ tym różnimy się od reszty, która obchodzi pierwszy i drugi dzień świąt :) (25.12.2019). Tak więc w czasie analizy poszczególne części artykułu hasłowego klasyfikować należy na podstawie cech funkcjonalnych, nie zaś formalnych.

Żaden z przeanalizowanych artykułów nie zawierał wszystkich dziewięciu wymienionych segmentów. W jednym haśle jest ich maksymalnie pięć. Jednak, jak napisano powyżej, za każdym razem może to być układ pięciu innych składników. I tak w przykładzie 7. pojawia się lemma (haj), definicja (nóż), cytat (Tutej często haje szły w ruch, a Eda miot nawet knare), ilustracja graficzna i hasło towarzyszące (knara), zaś w przykładzie 8. - lemma (kalafa), kwalifikator ( ruski miesiąc zapamiyntosz), stałe połączenia wyrazowe (drzeć kalafę itd.).

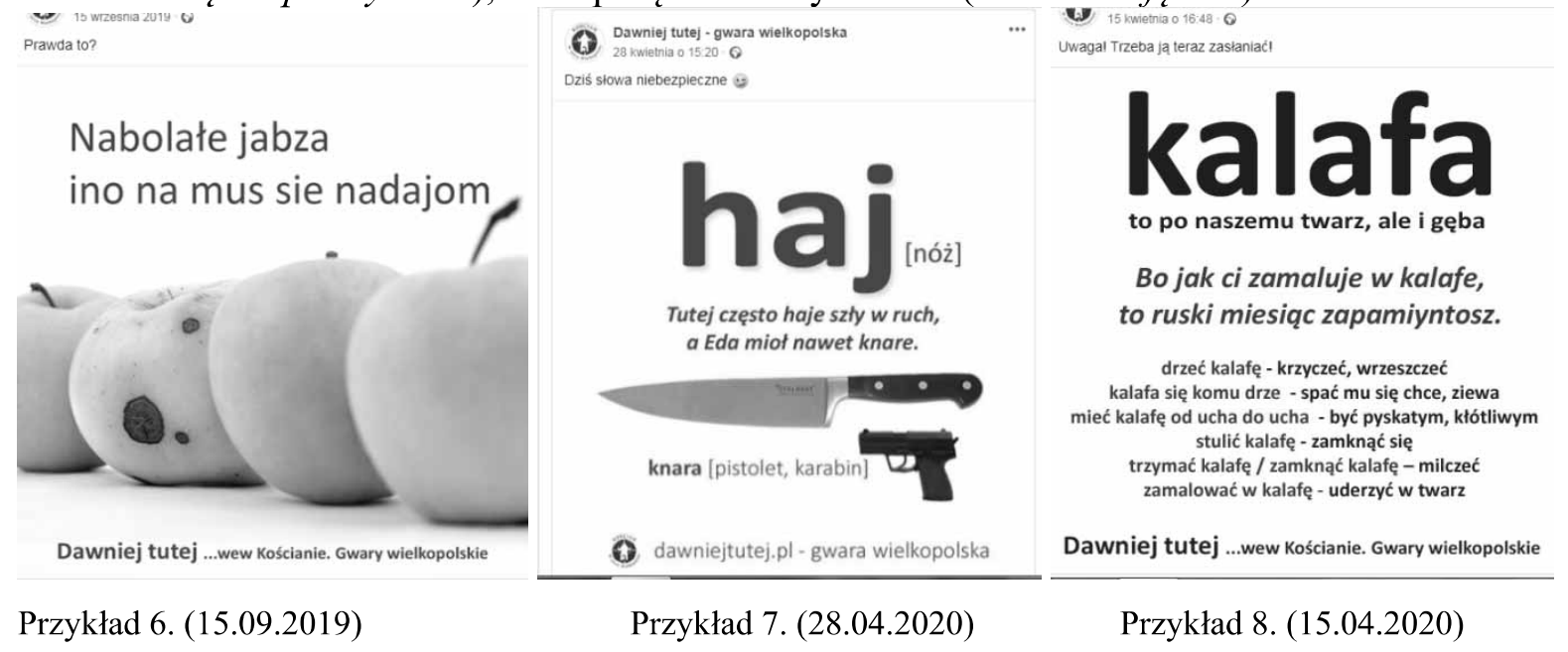

Minimalnie artykuł hasłowy składa się z dwóch elementów, którymi są wyraz hasłowy i definicja (7 przypadków) lub wyraz hasłowy i ilustracja graficzna (5). Ostatnia liczba zaskakuje osoby przyzwyczajone do tradycyjnych słowników gwarowych, ponieważ udział słowa pisanego jest tu ograniczony do minimum.

Wnioski i perspektywa badań. Jak pokazała analiza materiału, słownik $\mathrm{w}$ Internecie cechuje większe nastawienie na odbiorcę. Stąd pochodzi silne powiązanie publikowanych haseł z bieżącym kontekstem pozajęzykowym (stanem pogody, przypadającymi świętami, rocznicami itd.) oraz uatrakcyjnianie haseł, co wiąże się $z$ udziałem elementów graficznych $w$ artykule hasłowym oraz zmiennej formie tego ostatniego.

Dalszych badań wymagałby sposób opracowywania haseł słownikowych na innych fanpage'ach gwarowych. Należałoby także zwrócić uwagę na budowę artykułu hasłowego, dobór haseł (ich stosunek do odmiany ogólnej, potocznej czy regionalne). Na Facebooku funkcjonują fanpage'e poświęcone gwarom polskim oraz innym słowiańskim. Celowym są więc zarówne opracowania szczegółowe przedstawiające stan odnoszący się do konkretnych języków słowiańskich, jak i ujęcia porównawcze pozwalające wskazać na cechy uniwersalne oraz specyficzne poszczególnych źródeł.

Spis wykorzystanej literatury

1. Briggs A., Burke P. Społeczna historia mediów. Od Gutenberga do Internetu, tłum. J. Jedliński. Warszawa, 2010

2. Cemborowski B. Moda językowa na gwary wielkopolskie wśród użytkowników portalu społecznościowego Facebook. Dynamika rozwoju gwar słowiańskich w XXI wieku / pod red. D. K. Rembiszewskiej. Warszawa, 2017. S. 195-206. 
3. Cemborowski B. Funkcjonowanie gwar wielkopolskich w internecie. Przegląd wybranych form. Język $w$ regionie, region $w$ języku. T. 2 / pod red. B. Osowskiego. J. Kobus, P. Michalskiej-Góreckiej i A. PiotrowskiejWojaczyk. Poznań, 2017. S. 49-64.

4. Crystal D. The scope of Internet linguistics. URL : www.davidcrystal.com/?fileid=-4113 (dostęp 31.05.2020).

5. Czarnecka K. W poszukiwaniu tożsamości językowej - internetowa społeczność Howorymo po swojomu. Język $w$ regionie, region $w$ języku. T. 2 / pod red. B. Osowskiego, J. Kobus, P. Michalskiej-Góreckiej i A. Piotrowskiej-Wojaczyk. Poznań, 2017. S. 65-84.

6. Daković S. Słowniki tematyczne w Polsce, Serbii i Chorwacji. Südslavistik onlliine. Zeitschrift für südslavische Sprachen, Literaturen und Kulturen, 2011. NR 3. S. 33-52.

7. Dawniej tutej... - Fanpage Dawniej tutej - gwara wielkopolska. URL : https://www.facebook.com/ dawniejtutej/ (dostęp 30.04.2020).

8. Dębski R. Znaczenie elektronicznych komunikatorów dla języków mniejszościowych. Od mediów przekazu do mediów uczestniczenia. Transmisja i nauczanie języków mniejszościowych / red. R. Dębski, Kraków, 2008. S. 23-33.

9. van Dijk J. Społeczne aspekty nowych mediów. Analiza społeczeństwa sieci / przekład J. Konieczny. Warszawa, 2010.

10. Grzenia J. Komunikacja językowa w Internecie. Warszawa, 2006.

11. Karaś H. Polska leksykografia gwarowa. Warszawa, 2011.

12. Kucharzyk R. Frazeologizmy gwarowe w komunikacji internetowej. Annales Universitatis Paedagogicae Cracoviensis. Studia Linguistica, 2017, 12. S. $170-179$.

13. Momot A. Dialekt śląski na Facebooku. Dynamika rozwoju gwar słowiańskich w XXI wieku / pod red. D. K. Rembiszewskiej. Warszawa 2017, S. 207-219.

14. Osowski B. Gwary słowiańskie w nowym środowisku komunikacyjnym - Internet. Z polskich studiów slawistycznych. Seria 13. T. 2: Językoznawstwo. Prace na XVI Międzynarodowy Kongres Slawistów w Belgradzie 2018 / red. Z. Greń. Poznań, Wydawnictwo Naukowe UAM, 2018. S. 223-232.

15. Schneider S. M., Foot K. A. Sieć WWW jako przedmiot badań naukowych. Język@ multimedia 2. WWW - w sieci metafor. Strona internetowa jako przedmiot badań naukowych / red. A. Dytman-Stasieńko, J. Stasieńko. Wrocław, 2008. S. 23-33.

16. Smoleń-Wawrzusiszyn M. Socjolekty wirtualne - metody lingwistyki a komunikacja językowa w społecznościach sieciowych. Metody badań online / red. P. Siuda. Gdańsk, 2016. S. 182-234.

17. Urzędowska A. Komentarz na facebooku jako quasi-gatunek internetowy - język i typologia, «Język. Komunikacja. Informacja», 2019 / red. I. Koutny, I. Stria. S. 118-138.

18. Walczak B. Jak niespecjaliści piszą o językoznawstwie diachronicznym. Roczniki Humanistyczne, 2013. T. 61. Z. 6. S. 57-75.

19. Żebrowska B. Perspektywa badań ludowego słownego folkloru dziecięcego na przykładzie gwar okolic Krakowa. Dynamika rozwoju gwar słowiańskich w XXI wieku / pod red. D. K. Rembiszewskiej. Warszawa, 2017. S. 235-241.

20. Żmigrodzki P. Wprowadzenie do leksykografii polskiej. Wyd. 2 uzup. Katowice, 2005.

21. Żmigrodzki P. Słowo - słownik - rzeczywistość. Z problemów leksykografii i metaleksykografii. Kraków, 2008.

1. Briggs, A., Burke, P. (2010). Społeczna historia mediów. Od Gutenberga do Internetu [A Social History of the Media. From Gutenberg to the Internet], thum. J. Jedliński. Warszawa (In Pol.).

2. Cemborowski, B. (2017). Moda językowa na gwary wielkopolskie wśród użytkowników portalu społecznościowego Facebook [Greater Polish Dialects as a Linguistic Fashion among Facebook Users]. Dynamika rozwoju gwar słowiańskich w XXI wieku / pod red. D. K. Rembiszewskiej. Warszawa, 195-206 (In Pol.).

3. Cemborowski, B. (2017). Funkcjonowanie gwar wielkopolskich w internecie. Przegląd wybranych form [The function of the dialects of the Greater Poland in media space. The overwiev of selected forms]. Jezyk $w$ regionie, region $w$ języku. T. 2 / pod red. B. Osowskiego. J. Kobus, P. Michalskiej-Góreckiej i A. PiotrowskiejWojaczyk. Poznań, 49-64 (In Pol.).

4. Crystal, D. The scope of Internet linguistics. URL : www.davidcrystal.com/?fileid=-4113 (dostęp 31.05.2020) (In Eng1.).

5. Czarnecka, K. (2017). W poszukiwaniu tożsamości językowej - internetowa społeczność [In searching of language identity - virtual community Howorymo po swojomu]. In : Howorymo po swojomu. Język w regionie, region $w$ języku. T. 2 / pod red. B. Osowskiego, J. Kobus, P. Michalskiej-Góreckiej i A. Piotrowskiej-Wojaczyk. Poznań, 65-84 (In Pol.).

6. Daković, S. (2011). Słowniki tematyczne w Polsce, Serbii i Chorwacji [Thematic dictionaries in Poland, Serbia and Croatia]. In : Südslavistik onlliine. Zeitschrift für südslavische Sprachen, Literaturen und Kulturen. NR 3, 33-52 (In Pol.).

7. Dawniej tutej... - Fanpage Dawniej tutej - gwara wielkopolska [Fanpage Formerly here - Greater Poland dialect]. URL : https://www.facebook.com/dawniejtutej/ (dostęp 30.04.2020) (In Pol.). 
8. Dębski, R. (2008). Znaczenie elektronicznych komunikatorów dla języków mniejszościowych [The significance of electronic communication for minority languages]. In: Od mediów przekazu do mediów uczestniczenia. Transmisja i nauczanie języków mniejszościowych / red. R. Dębski, Kraków, 23-33 (In Pol.).

9. van Dijk, J. (2010). Społeczne aspekty nowych mediów. Analiza społeczeństwa sieci [The Network Society. Social Aspects of New Media] / przekład J. Konieczny. Warszawa (In Pol.).

10. Grzenia, J. (2006). Komunikacja językowa w Internecie [Linguistic communication on the Internet]. Warszawa (In Pol.).

11. Karaś, H. (2011). Polska leksykografia gwarowa [Polish dialectal lexicography]. Warszawa (In Pol.).

12. Kucharzyk, R. (2017). Frazeologizmy gwarowe w komunikacji internetowej [Dialectal phrasemes in the Internet communication]. In : Annales Universitatis Paedagogicae Cracoviensis. Studia Linguistica, 12, 170-179 (In Pol.).

13. Momot, A. (2017). Dialekt śląski na Facebooku [The silesian Dialect on Facebook]. In : Dynamika rozwoju gwar słowiańskich w XXI wieku / pod red. D. K. Rembiszewskiej. Warszawa, 207-219 (In Pol.).

14. Osowski, B. (2018). Gwary słowiańskie w nowym środowisku komunikacyjnym - Internet [Slavonic dialects in the new communication environment - Internet]. In : Z polskich studiów slawistycznych. Seria 13. T. 2: Językoznawstwo. Prace na XVI Międzynarodowy Kongres Slawistów w Belgradzie 2018 / red. Z. Greń. Poznań : Wydawnictwo Naukowe UAM, 223-232 (In Pol.).

15. Schneider, S. M., Foot, K. A. (2008). Sieć WWW jako przedmiot badań naukowych. Język @ multimedia 2. WWW - w sieci metafor. Strona internetowa jako przedmiot badań naukowych [The World Wide Web as a Research Object. Language [and] Multimedia 2. WWW - in the network of metaphors. Website as a subject of scientific research] / red. A. Dytman-Stasieńko, J. Stasieńko. Wrocław, 23-33 (In Pol.).

16. Smoleń-Wawrzusiszyn, M. (2016). Socjolekty wirtualne - metody lingwistyki a komunikacja językowa w społecznościach sieciowych [Virtual sociolects - methods of linguistics and linguistic communication in online communities]. In : Metody badań online / red. P. Siuda. Gdańsk, 182-234 (In Pol.).

17. Urzędowska, A. (2019). Komentarz na facebooku jako quasi-gatunek internetowy - język i typologia [Commentary on facebook as a quasi-internet genre - language and typology]. In : Język. Komunikacja. Informacja / red. I. Koutny, I. Stria. 118-138 (In Pol.).

18. Walczak, B. (2013). Jak niespecjaliści piszą o językoznawstwie diachronicznym [How Non-Specialists Write about Diachronic Linguistics]. In : Roczniki Humanistyczne». T. 61. Z. 6, 57-75 (In Pol.).

19. Żebrowska, B. (2017). Perspektywa badań ludowego słownego folkloru dziecięcego na przykładzie gwar okolic Krakowa [Research perspectives for verbal childlore of Cracow subdialects]. In : Dynamika rozwoju gwar słowiańskich w XXI wieku / pod red. D. K. Rembiszewskiej. Warszawa, 235-241 (In Pol.).

20. Żmigrodzki, P. (2005). Wprowadzenie do leksykografii polskiej [Introduction to Polish lexicography]. Wyd. 2 uzup. Katowice (In Pol.).

21. Żmigrodzki, P. (2008). Słowo - słownik - rzeczywistość. Z problemów leksykografii i metaleksykografii [Word - Dictionary - Reality. On the problems of lexicography and metallexicography]. Kraków (In Pol.).

\section{B. OSOWSKI. FANPAGE AS AN AMATEUR DIALECT DICTIONARY}

Summary. Introduction. Fanpage is a page created on Facebook, for fans of a well-known person, music band, sports team, social phenomenon etc. In this diverse, virtual space there is also a place for fans (or rather: supporters) of the dialect. This phenomenon is extremely interesting for the dialectologist due to the appearance of dialectal elements in the written code, while the original domain of using dialect is the spoken version of the language.

When discussing the collected material, the terminology of traditional lexicography was used, although this is only an adaptation of concepts and terms, because the online material is different from scientific dictionaries.

The aim of the article is to analyze the entry system and the construction of the entry.

Results. We are dealing with a set of dictionary entries, which are published according to variable criteria. If a series of related passwords appear, they are not ordered; rather, they form collections of loosely connected elements. Collections can be extracted on a semantic or formal basis. We also find traces of the nest system in the analyzed material. We also find another type of entries system, which appears probably most often. It is a system motivated by non-linguistic circumstances, such as the current weather, upcoming or celebrated holidays, regional traditions, anniversaries of important events.

In $99 \%$ of analyzed posts, the headword is a separate part of the entry. The definition appears almost as often - $91 \%$. Common elements of the entry include the graphics (72\%). Other elements are much less common.

Conclusion. The analysis of the material showed that the dictionary on the Internet is characterized by a greater focus on the recipient. This is a source of a strong connection between the published entries and the current non-linguistic context (weather conditions, falling holidays, anniversaries, etc.) and the attractiveness of entries, which involves the participation of graphic elements and the variable form of the entry.

Key words: dialectology, Internet, fanpage, post, dialect dictionary, lexicography, dictionary order, entry. 